\section{Genesis of the thermal-mineral waters of Ilidža, Bosnia and Herzegovina}

The Mining-Geology-Petroleum Engineering Bulletin UDC: 556.3

DOI: 10.17794/rgn.2019.11

Original scientific paper

\author{
Tatjana Vlahović'; Ferid Skopljak² \\ 'Croatian Natural History Museum; Demetrova 1, 10000 Zagreb, Croatia; tatjana.vlahović@hpm.hr \\ ${ }^{2}$ Federal Institute for Geology; Ustanička 11, 71210 Sarajevo, Bosnia \& Herzegovina; fskopljak@yahoo.com
}

\begin{abstract}
The springs of thermal-mineral waters (TMWs) of Ilidža near Sarajevo appear at the transition of the Central and Inner Dinarides of Bosnia and Herzegovina, at the overthrust front of the Bosnian Flysch and the far southeastern part of Sarajevo-Zenica Tertiary Basin. The wider area of Ilidža is composed of Mesozoic and Cenozoic deposits. The genesis of the TMWs of Ilidža was determined from the structural-tectonic relationships and hydrogeological features of the terrain, as well as from the analysis of hydrogeochemical indicators and isotopic compositions of water and gases. Hydrogeochemical methods included analysis of the hydrocarbon indicators, ionic ratio calculations and genetic classifications. The primary aquifer of TMWs of Ilidža are Permian-Triassic sediments with gypsum and anhydrites, and secondary aquifers are Triassic carbonates and alluvial deposits. The temperature of the TMWs resulted from the interaction of infiltration depth of atmospheric water and the geothermal gradient. Static pressure in the lenses of PermianTriassic deposits and the dynamic factors of TMWs, moving and ascending through porous rocks over long distances under extremely high pressures, contributed as well. The TMWs are of atmospheric origin and had no interaction with the atmospheric or surface waters since the year of 1953. TMWs are formed in the Upper Pleistocene, at the time of the cold climate within the epoch. Sulphates in TMWs originated from the Permian-Triassic evaporites. $\mathrm{H}_{2} \mathrm{~S}$ is produced under sulphate reducing conditions and $\mathrm{CO}_{2}$ is produced from metamorphosed carbonates.
\end{abstract}

Keywords:

aquifer genesis, thermal-mineral waters, sulphates, Ilidža

\section{Introduction}

The thermal-mineral water (TMW) springs of Ilidža near Sarajevo appear at the transition of the Central and Inner Dinarides of Bosnia and Herzegovina, i.e. the far southeastern part of the Zenica-Sarajevo Tertiary Basin. The first exploration of TMWs of Ilidža dates back to the 19th century and provides the grounds for the geological localization and genesis. Mojsisovics (1880) associated TMWs of Ilidža with mineral waters that appear from Busovača to Ilidža on a large displacement, along the southwest perimeter of the Tertiary Basin. Ludwig (1894) established that the chemical composition of the TMWs of Ilidža is very similar to the waters found at Ficoncella spring in Civitavecchia (Italy) and hot spring spas near Vienna. In the early $20^{\text {th }}$ century, Kittl (1904) linked the occurrence of TMWs of Ilidža with the Busovača Fault. Katzer (1919) stated that the origin of the formation of the TMWs of Ilidža is in Paleozoic Highlands, that probably lie under the shallow Sarajevo Basin. Katzer also stated that the TMW of Ilidža appears at the intersection of NW-SE faults with Vareš-Čevljanovici-Ulos Over-

Corresponding author: Dr. Tatjana Vlahović, Full Prof.

tatjana.vlahovic@hpm.hr turn and that it has properties of juvenile water. Bać (1957) linked hot steam in the inner area of the source of thermal origin in Ilidža to a post-volcanic event, and Josipović (1971) postulated the sedimentary origin of the TMW of Ilidža. Miošić (1982) classified the TMW of Ilidža into a hydrogeological structure that he named "artesian pools and inter-mountain depressions" with occurrences of TMWs with atmospheric-lake-continental origin. Skopljak and Čičić (2006) stated that the primary aquifer for the TMWs of Ilidža lies in the deposits of Permian-Triassic gypsum and anhydrite. Skopljak (2006) concluded that the temperature of TMWs is the result of interaction of the depth of infiltration of storm water and geothermal gradient, as well as the static pressure in the Permian-Triassic lenses due to the differentiation in Busovača Fault system and dynamic factors in movement and TMW ascendance through porous rocks under great pressure. Skopljak and Vlahović (2011) determined that the TMWs of the extreme southwestern rim of the Zenica-Sarajevo Basin are related to the Busovača Fault and that they primarily originate from evaporites of Permian age. The goal of this study is to determine the genesis of TMWs of Ilidža based on geological, structural-tectonic and hydrogeological features 
of the terrain, as well as any on available hydrogeochemical research conducted in the Ilidža area. Hydrogeochemical methods used in this paper include the analysis of hydrochemical indicators, genetic classification, and ionic budget relationships. As a supplement, the isotopic compositions of TMWs and gases were used. The content of stable $\left(\delta^{18} \mathrm{O}, \delta \mathrm{D} /{ }^{2} \mathrm{H},{ }^{13} \mathrm{C}, \delta^{34} \mathrm{~S},{ }^{13} \mathrm{C}\right.$, ${ }^{222} \mathrm{Ra}$ ), and radioactive $\left({ }^{3} \mathrm{H},{ }^{14} \mathrm{C}\right)$ isotopes in combination with the results of other research was used for evaluation of the origin of the water aquifer. Papić (2016) collected regional information and improved the knowledge of usage of the available hot water resources. Papić (2016) discussed the geology of SE Europe, mineral and thermal water potential, physical and chemical properties, as well as the utilization of thermal and mineral waters in Albania, Bosnia and Herzegovina, Bulgaria, Croatia, Macedonia, Montenegro, Romania, and Serbia. Skopljak et al. (2017) interpreted the genesis of the thermal waters from the northeast periphery of the Zenica-Sarajevo Basin based on the geological, structural-tectonic and hydrogeological characteristics of the terrain, as well as on the hydrogeochemical research conducted in the wider area. Among the more recent papers dealing with similar issues in the world, several must be emphasized. Goldscheider et al. (2010) presented the recent knowledge on thermal water resources in carbonate rock aquifers, discussed geochemical processes that created reservoir porosity and different types of utilisations of these resources such as thermal baths, geothermal energy and carbon dioxide sequestration. Petrini et al. (2013) defined the origin of low- to moderate-temperature thermal waters feeding the Monfalcone springs in Northern Italy. Maréchal et al. (2014) conducted a multidisciplinary study of a natural mineralized water system in Southern France. The study included geological mapping and core logging, geo-electrical profiling, piezometric interpretation, pumping and interference tests, time-series and statistical analysis, a MISO (multiple input single output) analysis, geochemical and isotopic characterization, and numerical modelling. Afsin et al. (2014) explained mixing processes as a dominant hydrogeological process in the hydrother- mal spring systems, and implications for interpreting geochemical data in the Cappadocia region of Turkey. In order to provide evidence on the recharge source of water and circulation dynamics of the Tangshan Geothermal System (TGS) near Nanjing (China), Lu et al. (2018), conducted a comprehensive study using multiple chemical and isotopic tracers $\left(\delta^{2} \mathrm{H}, \delta^{18} \mathrm{O}, \delta^{34} \mathrm{~S}\right.$, ${ }^{87} \mathrm{Sr} r{ }^{86} \mathrm{Sr}, \delta^{13} \mathrm{C},{ }^{14} \mathrm{C}$ and ${ }^{3} \mathrm{H}$ ). This study has provided key information on the genesis of TGS and the results are instructive to the effective management of the geothermal resources.

The objective of this study was to establish the origin of the TMWs of Ilidža near Sarajevo based on the geological, structural-tectonic and hydrogeological characteristics of the terrain, as well as on the hydrogeochemical research throughout the Ilidža area. In order to answer these questions, hydrogeochemical methods were used (hydrocarbon indicators analysis, ionic ratio calculations and genetic classifications). To verify the findings obtained in hydrogeochemical procedures, the isotopic composition of thermo-mineral water and gases was used. The content of stable isotopes $\left(\delta^{18} \mathrm{O}, \delta \mathrm{D} / 2 \mathrm{H}\right.$, $\left.\delta^{13} \mathrm{C}, \delta^{34} \mathrm{~S},{ }^{13} \mathrm{C},{ }^{222} \mathrm{Ra}\right)$ and radioactive isotopes $\left({ }^{3} \mathrm{H},{ }^{14} \mathrm{C}\right)$, along with the results of hydrogeochemical research, were used to assess the origin and dynamics of aquifer recharge.

\section{Study area}

The springs of the TMWs appear in Ilidža, about 10 $\mathrm{km}$ southwest of Sarajevo in the southwestern part of Sarajevo Field, which stretches NW-SE and sub-parallel to Igman Mt. (see Figure 1). The length of the field is 10 $\mathrm{km}$, the width is about $6 \mathrm{~km}$, and the altitude is about 500 $\mathrm{m}$ a.s.l. Mt. Igman (506 $\mathrm{m}$ a.s.l.), with many karst phenomena and karst springs, is a complex tectonic structure that has a great influence on the regime of groundwater in the southwestern part of the Sarajevo Basin. The hydrographic network of Ilidža belongs to the basin of Bosna River, including the tributaries of Željeznica, Večerica, Žujevina and Dobrinja.

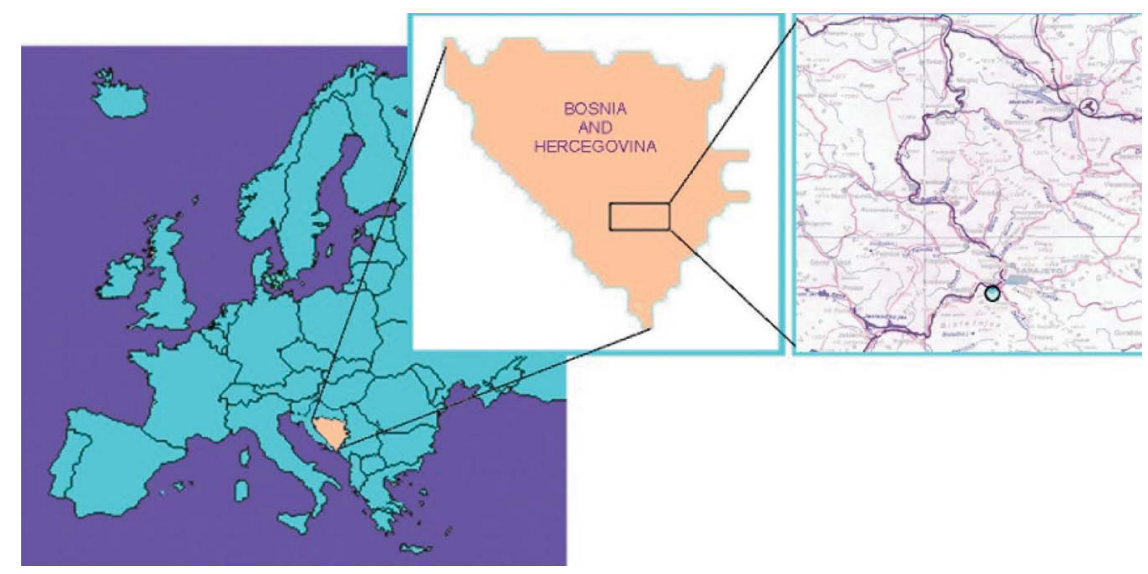

Figure 1: The geographic location of the TMW spring of Ilidža 


\section{Geological setting}

In the area of Ilidža, Mesozoic and Cenozoic deposits prevail (see Figure 2). Paleozoic deposits of Ilidža are not outcropping at the surface, but have been lowered into deeper parts of the terrain (see Figure 3). The Paleozoic deposits are sediments of Permian-to-Triassic age, consisting of conglomerates, clays, sandstones, and hollow limestones with gypsum and anhydrite lenses. Their presence at the base of the Triassic Igman Complex plays a very important role in the formation and maintenance of the regime of all types of groundwaters in this area (see Figure 3).
Mesozoic deposits include a variety of sedimentary flysch deposits of both Triassic and Cretaceous ages. The Triassic is represented by the Lower, Middle, and Upper Triassic deposits. The Lower Triassic is composed of sands, clays, and marls at the lower levels, and includes marls and limestones at the higher levels. The Middle Triassic deposits are dominant in the structures of Igman Mt. It is composed of Anisian limestones and dolomites, marls and tuffitic sandstones. The Middle-toUpper Triassic deposits are represented by limestones and partially by dolomites, and the Upper Triassic deposits predominantly consist of limestones. Upper Cretaceous Flysch is made of marls, sandstones, brec-

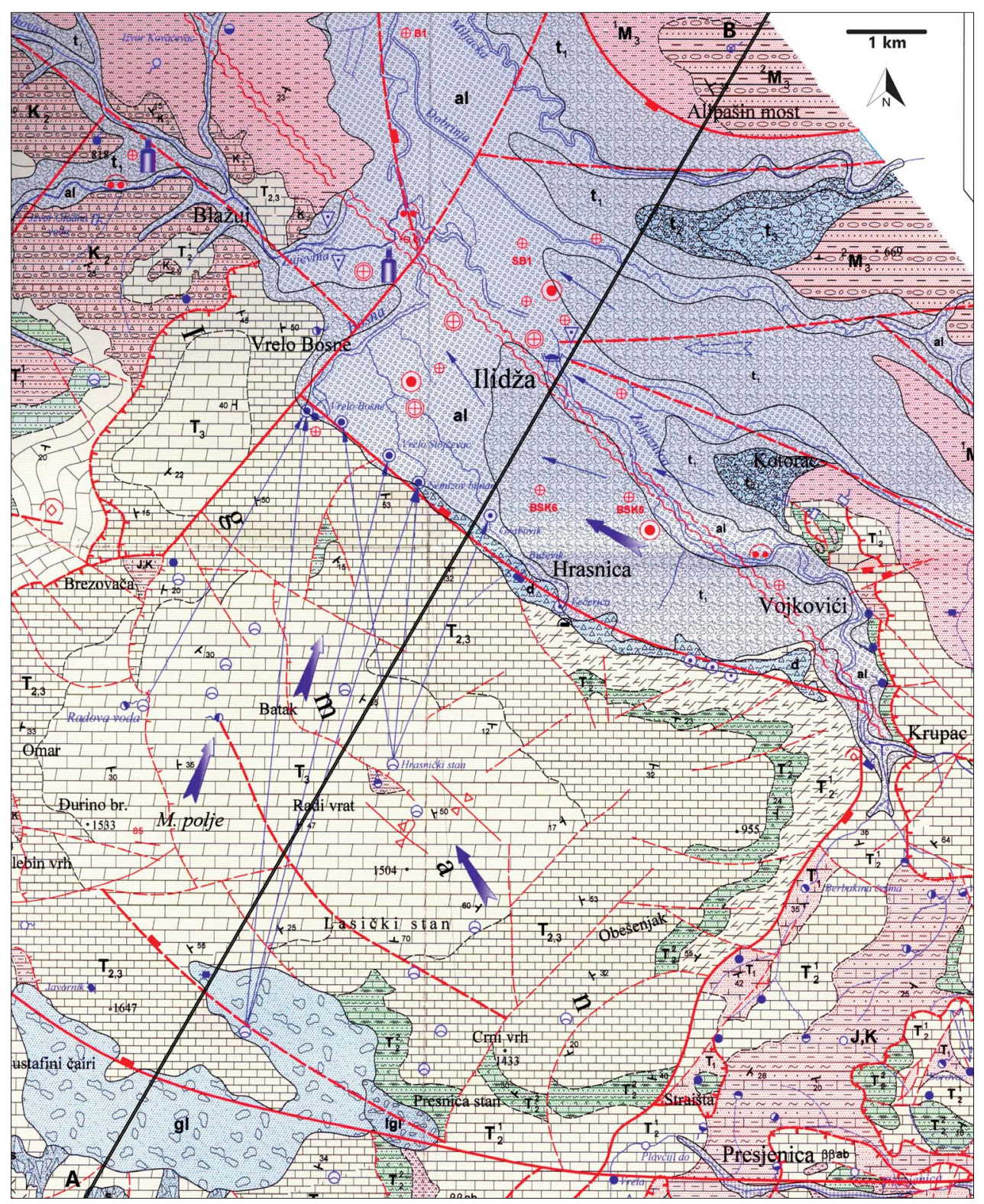

Figure 2: Hydrogeological map of the Ilidža area (Skopljak, 20o6).

LEGEND: 1. permeable rocks with intergranular porosity (al; $\left.\mathrm{d} ; \mathrm{gl} ; \mathrm{t}_{1}\right)$; 2. highly-permeable rocks with cracks - fracture porosity $\left(\mathrm{T}_{2}^{2}\right) ; 3$. highly-permeable rocks with cavernous - cracks/fracture porosity $\left(\mathrm{T}_{2}{ }_{2} ; \mathrm{T}_{2,3} ; \mathrm{T}_{3}\right)_{3}^{2} ; 4$. impermeable rocks

$\left({ }^{1} \mathrm{M}_{3} ;{ }^{2} \mathrm{M}_{3} ; \mathrm{J}, \mathrm{K} ; \mathrm{K}_{2}\right) ;$. certain underground connection $\longrightarrow$; 6. thermal-mineral waters flow direction 


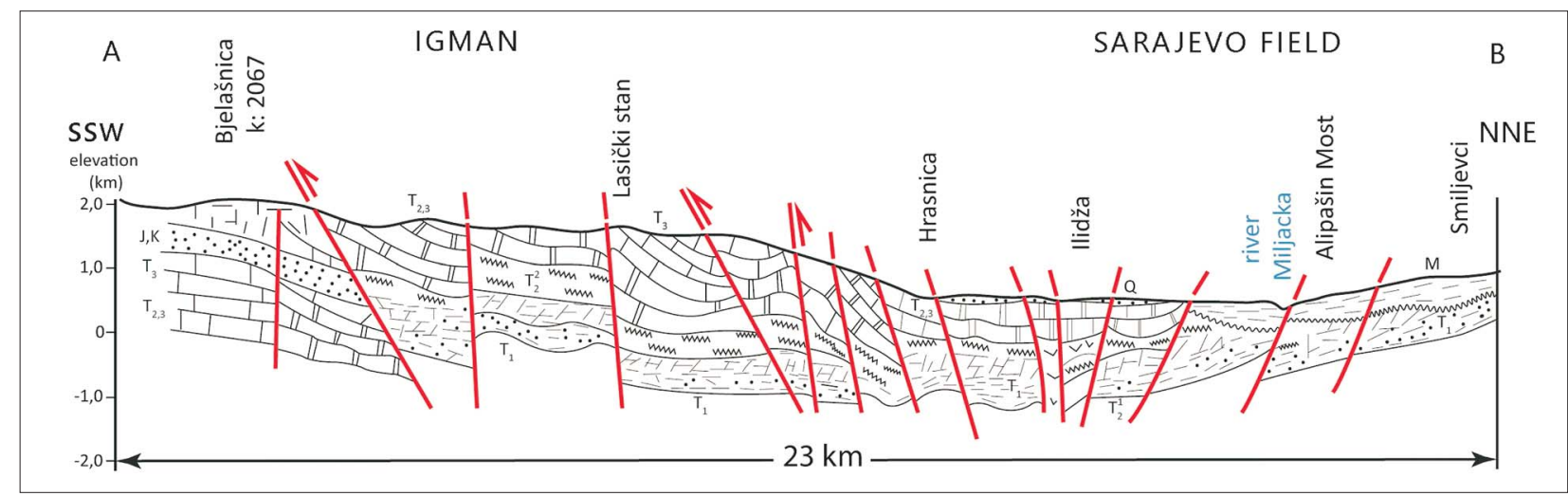

Figure 3: Geological profile Igman - Sarajevo Field (according to Skopljak, 2oo6). LEGEND: T - sandstone, marl and limestones; $\mathrm{T}_{2}{ }^{1}$ - limestones and dolomites; $\mathrm{T}_{2}{ }^{2}$ - sandstones, schists, cherts and limestones; $\mathrm{T}_{22}-$ limestones and dolomites; $\mathrm{T}_{3}^{2}$ - limestones with subordinate dolomite, $\mathrm{K}_{2}$ - limestones, calcarenites, marls and sandstones.

cias, calcarenitic limestones and brecciated limestones as well.

Cenozoic is represented by Neogene and Quaternary sediments. Miocene deposits were developed using Neogene sediments. The Miocene deposits are predominately clays, with alternating bands of marls, sandstones, and coals. Quartz deposits are Pleistocene and Holocene sediments. The Pleistocene sediments of the Sarajevo Basin are composed of limestones, clays and fine sands.

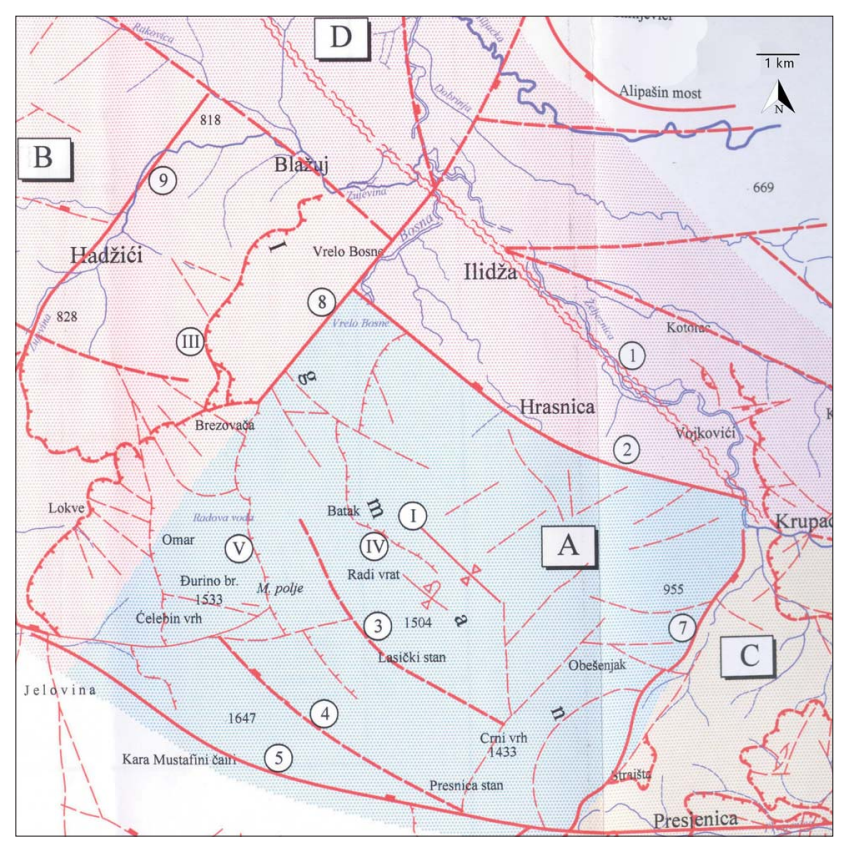

Figure 4: Tectonic map of Igman Mt. and SW part of Sarajevo Field (Skopljak, 20o6). LEGEND: A - Tectonic structures of Igman; B - Tectonic structures of Hadžići Rakovica; C - Tectonic structures of Krupac - Presjenica; D - Structural-facial unit of the Neogene Sarajevo-Zenica Basin; 1 - Busovača Fault; 2 - Igman Fault; 3 - Fault Suljine vode - Lasički stan; 4 - Fault Vučje Dole - Grkanica; 5 - Fault Krupa - Ravna vala - Presjenica; 7 - Krupa Fault; 8 - Fault Brezovača - Vrelo Bosne; 9 - Zujevine Fault; I - Igman Syncline; III - Blažuj-Lokve Overthrust; IV -Ravni - Batak - Krasnički stan Overthrust; V -Bresovača - Radova voda - M. Polje Overthrust.
Igman Mt. deposits consist of glacial sediments made of limestones, gravels, sands, and clays. Holocene is represented by alluvial deposits.

In the wider area of Ilidža, the most important tectonic structures, created by fracturing, faulting and horizontal movements, are: Igman Syncline, Busovača Fault Zone, Longitudinal and Transverse Faults, Durmitor Overthrust and Blažuj-Lokve-Krupa Overthrust. The Igman Syncline was formed between Bjelašnica in the southwest and the Sarajevo Field in the northeast, within clastics and carbonates. Some parts of the syncline are faulted, secondary folded and inverted. The Busovača Fault Zone has a so-called Dinaric direction of the structures (NW-SE), having numerous occurrences of mineral, thermal and thermomineral waters, abundant in $\mathrm{CO}_{2}$. Therefore, this zone has a great significance for the hydrogeological relations and genesis of the thermal waters of Ilidža. It ends in the southeastern part of the Sarajevo Field where it is divided in more regionally significant faults. The faults determined the tectonic and geomorphological structures of Igman Mt. and Sarajevo. The most important longitudinal fault is Bosna-Krupac Vrelo and the transversal fault is Brezovača-Vrelo Bosne. The Durmitor Overthrust, or its front, is separated from Presjenica Cliff to Sarajevo Field, north of Krupac (see Figure 4).

\section{Hydrogeological setting}

In the Ilidža area, two main categories of rocks were recognized: 1) permeable rocks and 2) impermeable rocks. The permeable rocks are based on the porosity, permeability, transmissibility, and the source and intensity of the springs: 1) the permeable rocks of the intergranular porosity; 2) highly-permeable rocks with cracks, and 3) highly-permeable rocks with cavernouscracks porosity (see Figure 2). The permeable walls of interstitial porosity are represented by alluvial deposits, predominantly made of gravels and sands. Based on the transmissibility, the specific capacity and the yield of the springs, these deposits are divided into weakly-perme- 
able, permeable, and highly-permeable rocks. The highly-permeable rocks with cracks are represented by the Permian-Triassic and Middle Triassic-Ladinian deposits. The highly-permeable rocks with cavernous-cracks porosity are limestones and Anisian dolomites of Middle-to-Upper and Upper Triassic age. High permeability is indicated by the presence of numerous underground karstic features, including karst springs with yields above $100 \mathrm{l} / \mathrm{s}$, large variations of minimum and maximum spring yields and high discharge coefficients of the karst springs. The source of TMWs of Ilidža is in these Triassic carbonate rocks. The impermeable rock deposits include mostly impermeable complexes and sometimes fully impermeable rocks. The predominantly impermeable complexes are represented by clastics of Lower Triassic age and Jurassic-to-Cretaceous and Upper Cretaceous Flysch (see Figure 2) clastic deposits. They act as a hydrogeological barrier. Fully impermeable rocks are clayey Miocene deposits and they act as a hydrogeological roof barrier.

\section{Methodology}

The genesis of the TMWs of Ilidža was determined based on geological structure, tectonic relationships and hydrogeological features of the terrain, as well as through the analysis of hydrogeochemical indicators and isotopic compositions of water and gases. Hydrogeochemical methods included analysis of the hydrocarbon indicators, ionic ratio calculations and genetic classifications. The spring of TMWs at Terme Ilidža, as well as IB-1, IB-2, PP-1, B-3a, B-10a, IB-10 and B-1 wells (see Figure 5) were analysed. The genetic classification of water is determined by the Sulin classification (1948) based on the primary ion ratio: $\mathrm{Na} / \mathrm{Cl}, \mathrm{Na}-\mathrm{Cl} / \mathrm{SO}_{4}$ and $\mathrm{Cl}-\mathrm{Na} / \mathrm{Mg}$. In addition to the findings of the hydrogeochemical methods used in the determination of the genesis of TMW, the isotopic compositions of TMWs and gases were also used. Isotopic analyses were carried out using deuterium $\left({ }^{2} \mathrm{H}\right)$ and oxygen $18\left({ }^{18} \mathrm{O}\right)$, tritium $\left({ }^{3} \mathrm{H}\right)$, sulphur $34\left({ }^{34} \mathrm{~S}\right)$ for sulphates, carbon $13\left({ }^{13} \mathrm{C}\right)$, carbon 14

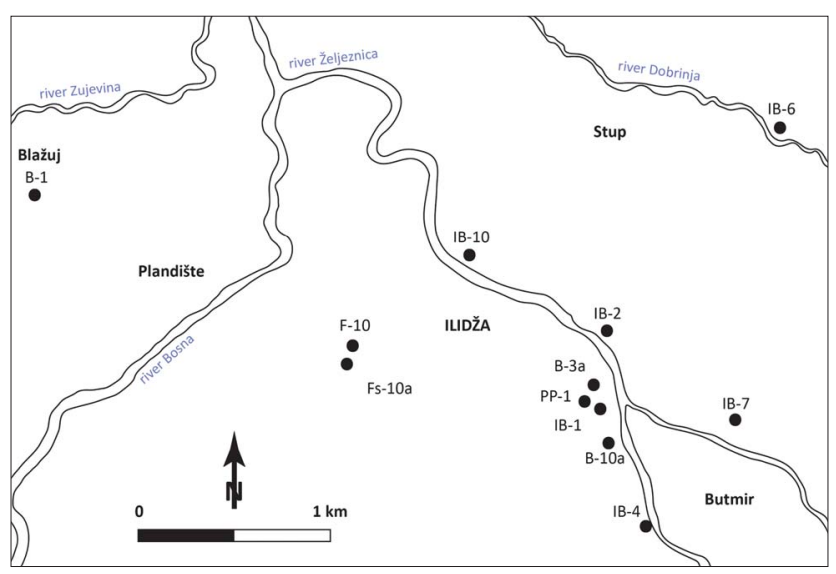

Figure 5: The location of well drillholes of TMWs of Ilidža (according to Skopljak, 2006) $\left({ }^{14} \mathrm{C}\right)$ and radon $\left({ }^{222} \mathrm{Ra}\right)$ (Pezdič et. al., 1985, 1987; Heidinger, 2000).

\section{Results}

\subsection{Hydrogeological settings}

The TMWs of Ilidža are primarily accumulated in the Permian-Triassic gypsum deposits. From there, TMWs flow into the Triassic carbonates and alluvial deposits that are observed in numerous well drillholes. Wells IB1, IB-2, PP-1, B-3a, B-10a, IB-10, and B-1 are further investigated (see Figure 5). The IB-1 well is located on the left bank of Željeznica River. It was drilled in 1984 to a depth of $43.7 \mathrm{~m}$. TMW is found in Quaternary sandgravel sediments and conglomerates. The well has a capacity of $75 \mathrm{l} / \mathrm{s}$ at the drawdown of 14-meters. The IB-2 well is located on the right bank of Željeznica River. TMW is found in dolomitic limestones at a depth of 47 $\mathrm{m}$. The borehole transmission was determined to be 3.3 $x 10^{-2} \mathrm{~m}^{2} / \mathrm{s}$ with a hydraulic conductivity coefficient of $1.64 \times 10^{-4} \mathrm{~m} / \mathrm{s}$, and a maximum capacity of $100 \mathrm{l} / \mathrm{s}$. The PP-1 well is about $30 \mathrm{~m}$ away from the IB-1 well. It was drilled in 1964 to a depth of $90 \mathrm{~m}$. TMW was found in limestones and dolomites, with a discharge of $50 \mathrm{l} / \mathrm{s}$. The B-3a well was drilled in 1971. TMW is found in alluvial sediments, after inflowing from dolomitic limestones. The discharge was found to be $10-201 / \mathrm{s}$. The B-10A well is located approximately $100 \mathrm{~m}$ from the IB-1 well. The drillhole depth is $77.1 \mathrm{~m}$ and it was drilled in alluvial sandy-gravel sediments. The discharge was found to be $10-15 \mathrm{l} / \mathrm{s}$. The IB-10 well was drilled to a depth of $1140 \mathrm{~m}$. The karst aquifer accumulated TMW and it is found at depths of 355 to $1100 \mathrm{~m}$. The limestone roof contains the clayey-marl Tertiary sediments of the Sarajevo-Zenica Basin at a depth of 22 to $355 \mathrm{~m}$. The well is artisan, with a discharge of $27 \mathrm{l} / \mathrm{s}$. The transmissibility was $6.54-8.14 \times 10^{-3} \mathrm{~m}^{2} / \mathrm{s}$ and the hydraulic conductivity coefficient for stationary conditions was found to be $1.32 \times 10^{-2} \mathrm{~m} / \mathrm{s}$. The B-1 well was drilled in 1999 to a depth of $105 \mathrm{~m}$. TMW was found in the Triassic dolomites directly beneath the alluvium. The discharge was found to be about $11.5 \mathrm{l} / \mathrm{s}$.

\subsection{Hydrochemistry}

The average hydrochemical values of the TMWs of Ilidža are shown in Table 1. The hottest TMWs (57$58^{\circ} \mathrm{C}$ ) appear in the area of Banja, on Ilidža. They are found in wells IB-1, IB-2, PP-1 and B-3a in the Triassic carbonates below the Quaternary deposits. An important feature of these TMWs is high water mineralization, ranging from 2700 to $4100 \mathrm{mg} / 1$ (see Figure 6).

The increase in mineralization follows the increase of concentrations of major cations and anions in water: sodium, hydrocarbonates, sulphates and chlorides (see Figure 7), as well as relatively high hydrogen-sulphide content. TMWs belong to the $\mathrm{HCO}_{3}-\mathrm{SO}_{4}-\mathrm{Cl}-\mathrm{Ca}-\mathrm{Na}$ type 


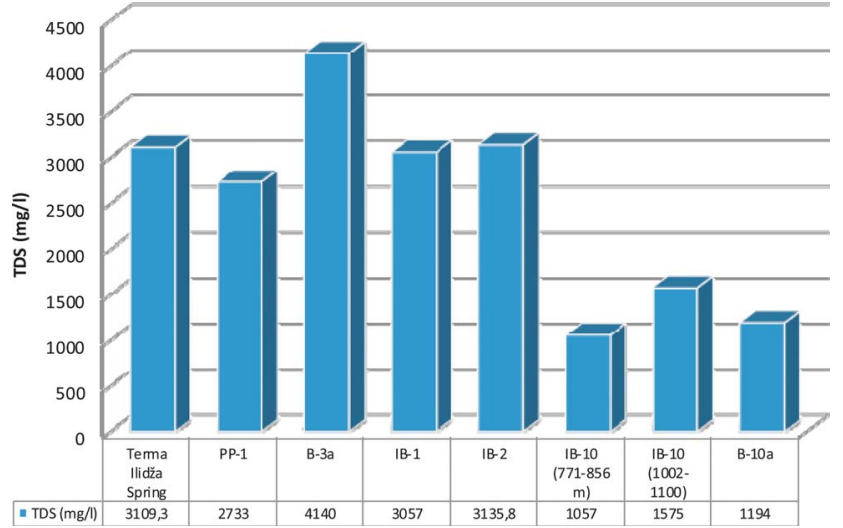

Figure 6: Water mineralization of the TMWs of Ilidža

of water. Other wells that are located laterally from the wells mentioned above have a significantly different chemical composition, and significantly lower temperatures and mineralizations (see Figure 6). These colder wells are represented by B-10a and IB-10. The B-10a drillhole found TMW in the Triassic carbonates, and the IB-10 well in the brecciated limestones. Water temperatures range from about 20 to $30^{\circ} \mathrm{C}$, and mineralization ranges from 1100 to $1600 \mathrm{mg} / \mathrm{l}$ (see Figure 6). TMW found in this well is $\mathrm{HCO}_{3}-\mathrm{Ca}$ type with relatively low sulphate and sulphur content. Not far from Ilidža, in Blažuj, there are also sources of TMWs, but of a different chemical composition. The B-1 borehole is representative for that. The TMW sampled at the well is a $\mathrm{HCO}_{3}$ $\mathrm{SO}_{4}$-Ca-Mg type, with a temperature of $24^{\circ} \mathrm{C}$, mineralization of about $2,500 \mathrm{mg} / \mathrm{l}$ and no sulphates.

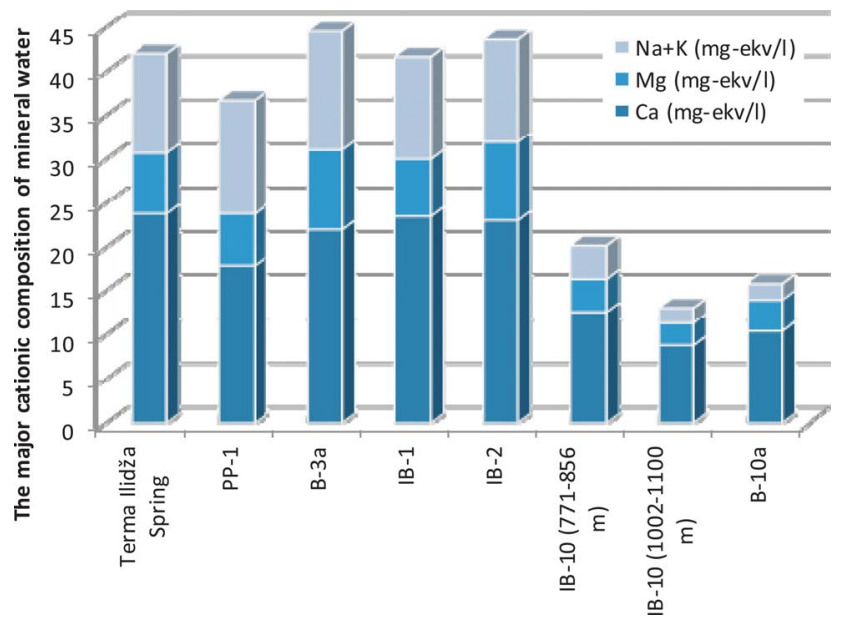

Figure 7: Proportions of main ions of the TMWs of Ilidža

Table 1: Chemical composition of the TMWs of Ilidža

\begin{tabular}{|c|c|c|c|c|c|c|c|c|}
\hline \multicolumn{9}{|c|}{ Sampling sites } \\
\hline \multirow[t]{2}{*}{ Components } & \multirow{2}{*}{$\begin{array}{c}\text { Terma Ilidža } \\
\text { spring }\end{array}$} & \multirow{2}{*}{$\begin{array}{c}\text { Borehole } \\
\text { PP-1 }\end{array}$} & \multirow{2}{*}{$\begin{array}{c}\text { Borehole } \\
\text { B-3a }\end{array}$} & \multirow{2}{*}{$\begin{array}{c}\text { Borehole } \\
\text { IB-1 }\end{array}$} & \multirow{2}{*}{$\begin{array}{c}\text { Borehole } \\
\text { IB-2 }\end{array}$} & \multicolumn{2}{|c|}{ Borehole IB-10 } & \multirow{2}{*}{$\begin{array}{c}\text { Borehole } \\
\text { IB-10a }\end{array}$} \\
\hline & & & & & & $771-856 \mathrm{~m}$ & $1002-1100 \mathrm{~m}$ & \\
\hline Temperature ${ }^{\circ} \mathrm{C}$ & 57.2 & 58 & 57 & 58 & 58.3 & 30.5 & 20.5 & 26 \\
\hline $\mathrm{pH}$ & & 6.5 & 6.5 & 6.6 & 6.9 & 6.71 & 6.76 & 6.4 \\
\hline TDS (mg/L) & 3109.3 & 2733 & 4140 & 3057 & 3135.8 & 1057 & 1575 & 1194 \\
\hline TH $\left({ }^{0} n \mathbf{j}\right)$ & & 66.7 & 86.8 & & 91.26 & 46.8 & 31.5 & 38.97 \\
\hline $\mathrm{Ca}^{2+}(\mathrm{mg} / \mathrm{L})$ & 473.7 & 355 & 440 & 470 & 464.5 & 260.5 & 177 & 208.2 \\
\hline $\mathrm{Mg}^{2+}(\mathrm{mg} / \mathrm{L})$ & 83.8 & 73.2 & 109.8 & 79.3 & 108.4 & 45 & 34 & 42.6 \\
\hline $\mathrm{Na}^{+}(\mathrm{mg} / \mathrm{L})$ & 261.7 & 285.7 & 300 & 260 & 263 & 80.5 & 36.6 & 40.2 \\
\hline $\mathrm{K}^{+}(\mathrm{mg} / \mathrm{L})$ & 14 & 17.4 & 18.2 & 14 & 9.16 & 15.6 & 0.97 & 3.4 \\
\hline $\mathbf{A l}^{3+}(\mathbf{m g} / \mathrm{L})$ & & 0.25 & 0.14 & 0.45 & 0.09 & 23.8 & 54 & 0.2 \\
\hline $\mathrm{Fe}^{3+}(\mathrm{mg} / \mathrm{L})$ & & 2.5 & 0 & 0 & 0 & 5.2 & 0.75 & 0.4 \\
\hline $\mathrm{HCO}_{3}^{-}(\mathrm{mg} / \mathrm{L})$ & 1327 & 1372.5 & 1293.2 & 1342 & 1342 & 908.9 & 683.2 & 768.6 \\
\hline $\mathrm{SO}_{4}{ }^{2-}(\mathrm{mg} / \mathrm{L})$ & 541.1 & 250 & 750 & 500 & 570 & 170 & 65.6 & 49.5 \\
\hline $\mathrm{Cl}^{-}(\mathrm{mg} / \mathrm{L})$ & 327.7 & 326.6 & 284 & 320 & 340.8 & 90.2 & 44.4 & 73.5 \\
\hline $\mathrm{H}_{2} \mathrm{~S}(\mathrm{mg} / \mathrm{L})$ & & & 0.34 & 0.1 & 0.88 & 0 & 0 & 0.03 \\
\hline $\mathrm{Br}(\mathrm{mg} / \mathrm{L})$ & & 0.3 & 0.3 & 0.5 & 0.07 & & & 0.07 \\
\hline $\mathrm{J}^{-}(\mathrm{mg} / \mathrm{L})$ & & 0.07 & 0.03 & 0.1 & 0.03 & & & 0.02 \\
\hline $\mathrm{F}(\mathrm{mg} / \mathrm{L})$ & & 0.8 & 1.28 & 1.05 & 0.75 & 0.39 & 0.48 & 0.35 \\
\hline $\mathrm{SiO}_{2}(\mathrm{mg} / \mathrm{L})$ & & 47 & 42 & 50 & 53 & & 2.5 & 12 \\
\hline $\mathrm{Li}^{+}(\mathrm{mg} / \mathrm{L})$ & & 0.65 & 0.7 & 0.66 & 0.68 & & & 0.18 \\
\hline $\mathrm{Sr}^{2+}(\mathrm{mg} / \mathrm{L})$ & & 2 & 2.3 & 3.25 & 2.6 & & 298 & 0.67 \\
\hline $\mathrm{Mn}^{2+}(\mathrm{mg} / \mathrm{L})$ & & 0.18 & 0.1 & & 0.11 & & $<5$ & 0.28 \\
\hline $\mathrm{Zn}^{2+}(\mathrm{mg} / \mathrm{L})$ & & 0.1 & 0.03 & 0.01 & 0.02 & 0.85 & 3.9 & 0.02 \\
\hline $\mathrm{Cu}^{2+}(\mathrm{mg} / \mathrm{L})$ & & 0 & 0 & 0 & 0.003 & 3.7 & 2.4 & 0 \\
\hline $\mathrm{CO}_{2}(\mathrm{mg} / \mathrm{L})$ & & 660 & 431.2 & 260 & 420 & 440 & 352 & 538 \\
\hline
\end{tabular}


Table 2: Ionic relationships of the TMWs of Ilidža

\begin{tabular}{|c|c|c|c|c|c|c|c|c|}
\hline \multirow[t]{2}{*}{ Sampling sites } & $\frac{\mathrm{Na}}{\mathrm{Ca}}$ & $\frac{\mathrm{Na}-\mathrm{Cl}}{\mathrm{SO}_{4}}$ & $\frac{\mathrm{Cl}}{\mathrm{SO}_{4}}$ & $\frac{\mathrm{HCO}_{3}}{\mathrm{Cl}+\mathrm{SO}_{4}}$ & $\frac{\mathrm{Mg}}{\mathrm{Ca}}$ & $\frac{\mathrm{Na}}{\mathrm{Cl}}$ & $\frac{\mathrm{Ca}}{\mathrm{Na}+\mathrm{Mg}}$ & $\frac{\mathrm{Cl}-\mathrm{Na}}{\mathrm{Mg}}$ \\
\hline & \multicolumn{8}{|c|}{ mg-ekv/l } \\
\hline Terma Ilidža spring & 0.48 & 0.18 & 0.83 & 1.06 & 0.29 & 1.22 & 1.30 & -0.30 \\
\hline PP-1 & 0.70 & 0.62 & 1.77 & 1.56 & 0.34 & 1.35 & 0.96 & -0.54 \\
\hline B-3a & 0.59 & 0.32 & 0.51 & 1.09 & 0.41 & 1.63 & 0.99 & -0.56 \\
\hline IB-1 & 0.48 & 0.22 & 0.87 & 1.13 & 0.28 & 1.25 & 1.32 & -0.35 \\
\hline IB-2 & 0.50 & 0.15 & 0.81 & 1.02 & 0.39 & 1.19 & 1.13 & -0.21 \\
\hline IB-10 (771-856 m) & 0.28 & 0.27 & 0.72 & 2.45 & 0.28 & 1.38 & 1.74 & -0.26 \\
\hline IB-10 $(1002-1100 \mathrm{~m})$ & 0.18 & 0.38 & 0.85 & 4.06 & 0.29 & 1.45 & 2.15 & -0.20 \\
\hline B-10a & 0.17 & -0.32 & 2.01 & 4.06 & 0.34 & 0.85 & 1.98 & 0.09 \\
\hline
\end{tabular}

\section{Ionic relationships}

The ionic relationships of TMWs of Ilidža are shown in Table 2.

The inter-ionic ratio of $\mathrm{Cl} / \mathrm{SO}_{4}$ is uniform in most sampling sites ranging from 0.51 to 0.85 and $\mathrm{SO}_{4} /$ $\mathrm{Cl}>1.6$, and according to Buljan (1962) the TMWs belong to the sulphate type of water. The exceptions are the PP-1 and B-10a wells where the $\mathrm{Cl} / \mathrm{SO}_{4}$ ratios are 1.77 and 2.01 respectively. The values of the anion ratio of $\mathrm{HCO}_{3} / \mathrm{Cl}+\mathrm{SO}_{4}$ from the samples from wells on the left bank of Željeznica River range from 1.02 to 1.56 while on the right bank the values are higher and range from 2.45 to 4.06 . The obtained values are a consequence of the relatively high total sulphate and chloride content relative to the content of the hydrocarbonate ion because the groundwater flow is carried out through gypsumanhydrite deposits. The ratio of $\mathrm{Mg} / \mathrm{Ca}$ ranges from 0.28

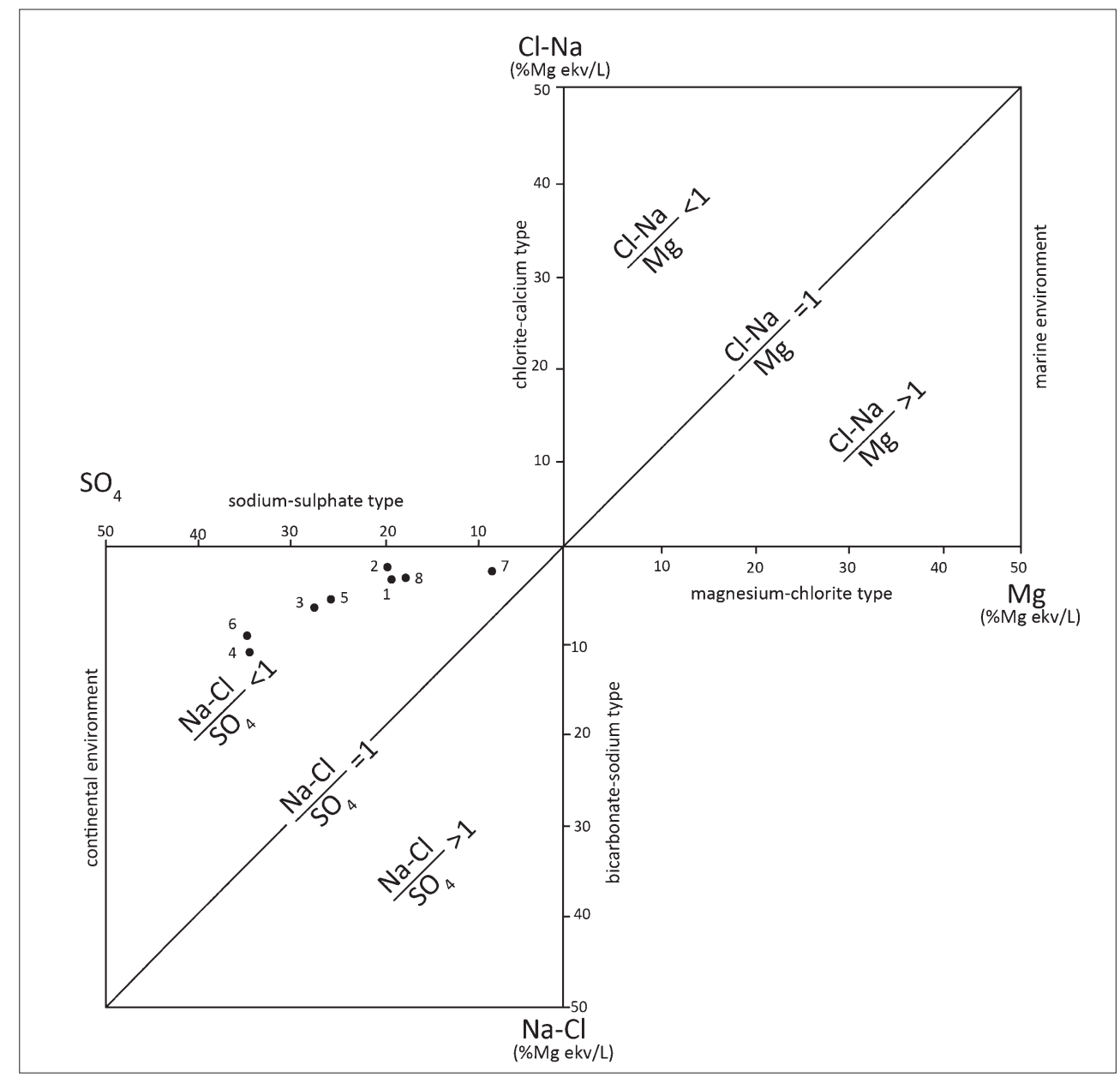

Figure 8: Sulin’s Diagram for the genetic classification of TMWs of Ilidža 1 - Spring Blažuj (1957); 2 - B-1 Blažuj (1999); 3 - Spring Terma Ilidža (1890); 4 - B-3a (1984); 5 - IB-1 (1985); 6 - IB-2 (1986); 7 - B-10a (1982); 8 - IB-10 (2004). 
Table 3: The isotopic composition of TMWs of Ilidža

\begin{tabular}{|c|c|c|c|c|c|c|c|c|c|c|}
\hline Number & Object & Year & $\begin{array}{l}\delta^{2} \mathrm{H} \\
\% 0^{-}{ }_{\text {vsmow }}\end{array}$ & $\begin{array}{l}\delta^{18} \mathrm{O} \\
\%^{0-}{ }^{-} \text {vsmow }\end{array}$ & $\begin{array}{l}\delta^{34} \mathrm{~S} \\
\% 0^{-} \mathrm{CD}\end{array}$ & $\begin{array}{l}\delta^{13} \mathrm{C} \\
\% 0^{-} \\
\text {VPDB }\end{array}$ & $\begin{array}{l}{ }^{3} \mathrm{H} \\
\mathrm{TU}\end{array}$ & $\begin{array}{l}\delta^{14} \mathrm{C} \\
\mathrm{pcm}\end{array}$ & ${ }^{32} \mathrm{~S} /{ }^{34} \mathrm{~S}$ & $\begin{array}{l}{ }^{122} \mathrm{Ra} \\
\mathrm{Bq} / \mathrm{l}\end{array}$ \\
\hline 1. & Fontana & 1984 & -76.5 & -10.35 & 12.49 & 0.96 & - & - & 21.94 & 1.43 \\
\hline 2. & B-3a & 1984 & - & & & - & $<1.7$ & $32937+/-3000$ & - & - \\
\hline 3. & IB-1 Ilidža & 1985 & -72.3 & -10.20 & 11.20 & 2.44 & - & - & 21.97 & 1.50 \\
\hline 4. & IB-2 Ilidža & 1987 & -78.0 & -10.31 & 7.38 & 1.14 & $<1.7$ & $13593+/-359$ & 22.05 & 1.40 \\
\hline 5. & B-1 Blažuj & 2000 & -74.4 & -10.55 & 23.2 & -1.5 & 1.8 & - & - & 2.3 \\
\hline
\end{tabular}

Table 4: Content and isotopic composition of free gases

\begin{tabular}{|c|c|c|c|c|c|c|c|c|c|}
\hline Number & Object & Year & $\begin{array}{l}\mathrm{O}_{2} \\
\text { Vol. \% }\end{array}$ & $\begin{array}{l}\mathrm{N}_{2} \\
\text { Vol. \% }\end{array}$ & $\begin{array}{l}\text { Ar } \\
\text { Vol. \% }\end{array}$ & $\begin{array}{l}\mathrm{CH}_{4} \\
\text { Vol. \% }\end{array}$ & $\begin{array}{l}\mathrm{CO}_{2} \\
\text { Vol. \% }\end{array}$ & $\begin{array}{l}\delta^{18} \mathrm{O} \\
\%{ }^{-}{ }^{-} \text {VPDB }\end{array}$ & $\begin{array}{l}\delta^{13} \mathrm{C} \\
\% 0^{-}{ }_{\text {VPDB }}\end{array}$ \\
\hline 1. & Fontana & 1984 & 0.1 & 1.2 & 0.01 & 0.01 & 98.6 & -12.21 & -2.36 \\
\hline 3. & IB-1 Ilidža & 1985 & 0.4 & 1.46 & 0.04 & 0.01 & 98.1 & - & -0.18 \\
\hline 4. & IB-2 Ilidža & 1987 & 0.1 & 0.4 & 0.05 & 0.1 & 99.3 & -14.85 & -1.75 \\
\hline 5. & B-1 Blažuj & 2000 & 0.1 & 11.8 & 0.2 & $<0.1$ & 87.9 & - & -3.7 \\
\hline
\end{tabular}

to 0.41 , that is less than 1 , indicating that the TMW drains from the area where the limestones have had $\mathrm{Ca}^{2+}$ replaced with some amounts of $\mathrm{Mg}^{2+}$, that is, the aquifer hosting rocks along with limestone also have dolomite limestones and dolomites. The ratio of $\mathrm{Na} / \mathrm{Cl}>1$, except for the $\mathrm{B}-10 \mathrm{a}$ well, indicates that the cation origin is partly related to the hydrolysis of aluminosilicates from the flysch or from the soil (Hem, 1985), and is partly the result of the dissolution of Na-sulphate minerals. The $\mathrm{Ca} / \mathrm{Na}+\mathrm{Mg}$ ratio ranges from 0.96 to 2.15 , with more values being obtained in TMW on the right bank of Željeznica River. $\mathrm{Ca} / \mathrm{Na}+\mathrm{Mg}>2$ indicates that Ca content is very high (over $65 \% \mathrm{mg}$-eq), indirectly indicating groundwater flow through limestone or calcium-sulphate rocks (gypsum-anhydrite). The $\mathrm{Ca} / \mathrm{Na}+\mathrm{Mg}=1-2$ is characterized by groundwater with a $\mathrm{Ca}$ content of 50 to $60 \% \mathrm{mg}$-eq, and slightly less or nearly equivalent to the total content of $\mathrm{Mg}$ and $\mathrm{Na}$ ions. The low values of this $\mathrm{Ca} / \mathrm{Na}+\mathrm{Mg}$ ratio are characteristic for groundwater in which $\mathrm{Ca}$ content is less than $50 \% \mathrm{mg}$-eq, has increased $\mathrm{Na}$ and $\mathrm{Mg}$ content (45-60\% mg-eq), implying that the groundwater flows through dolomite. The $\mathrm{Na} / \mathrm{Ca}$ ratio of TMWs is less than 1 in all the wells.

\section{Genetic classification}

TMWs of Ilidža have $\mathrm{Na} / \mathrm{Cl}>1$ except for the B-10a well, and the $\mathrm{Na}-\mathrm{Cl} / \mathrm{SO}_{4}$ ratio ranges from -0.32 to 0.62 . According to Sulin (1948), TMWs with $\mathrm{Na} / \mathrm{Cl}>1$ and $\mathrm{Na}-\mathrm{Cl} / \mathrm{SO}_{4}<1$ belong to the sulphate-sodium type and originate from a land-based medium (see Figure 8). Sodium sulphate may occur in three different ways: partly as a result of the exchange of ions in a reaction between dissolved calcium-sulphate in water and sodium cation absorption from the rocks, during the mixing of sulphate-calcium-magnesium water with hydrocarbonate-sodium water, or as a result of the dissolution of the gypsum deposits (Gavrilenko, 1965). TMWs of
Ilidža most likely originated due to the dissolution of gypsum deposits, which make up an important part of the Permian-Triassic deposits in this area.

\section{Isotopic composition}

The isotopic composition of water and free gases is shown in Tables 3 and 4 (Pezdič et al., 1985, 1987; Heidinger, 2000).

\section{Discussion}

In the Ilidža area, the chemistry of TMWs is closely related to deposits that drain or precipitate a part of the dissolved substances in TMWs by dissolving rocks or minerals that build aquifers. The primary aquifers of TMWs are the larger Permian-Triassic gypsum-anhydrite lenses, the quartz sandstones of the Lower Triassic, and the carbonates of Middle Triassic (Anisian) and Middle-to-Upper Triassic. Atmospheric water infiltrates the Igman area through the interstitial surfaces, and through normal and transverse faults as well. Water in the Igman area infiltrates at a depth of over $1 \mathrm{~km}$. Moderately heated water dissolves gypsum anhydrite lenses and is enriched with sulphates. The infiltration of water to a greater depth, very slowly, continues in the direction of the Sarajevo Basin to the primary aquifer. In the Sarajevo Basin, where the Permian-Triassic and Triassic deposits have been uplifted, the TMWs ascendantly move to the springs. The genesis of TMWs of Ilidža is shown in Figure 9.

Several sources of TMWs have been identified in the Ilidža area. They significantly differ in temperature, mineralization, chemical composition and the presence of gases, and are caused by differences in the geological composition and structural features of the terrain in which they are found. 


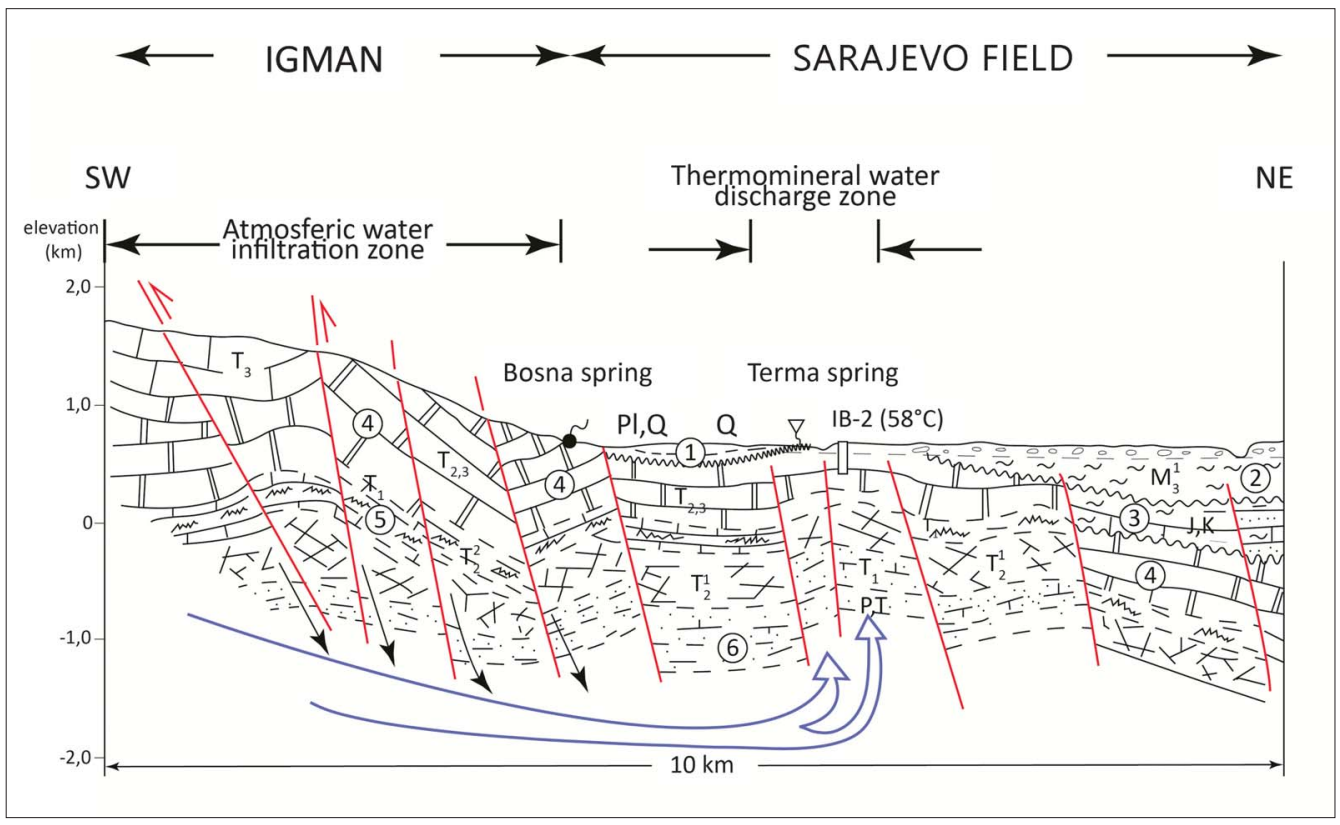

Figure 9: The model of formation of TMWs of Ilidža. LEGEND: 1. Porous rocks of intergranular porosity $(\mathrm{Q}, \mathrm{Pl}, \mathrm{Q}) ; 2$. Practically non-porous rocks $\left(\mathrm{M}_{3}{ }^{1}\right)$; 3. Predominantly non-porous complex $(\mathrm{J}, \mathrm{C}) ; 4$. Porous rocks of cavernous-fracture porosity $\left(\mathrm{T}_{2}{ }_{2}, \mathrm{~T}_{2,3}, \mathrm{~T}_{3}\right) ; 5$. Porous rocks of fracture porosity $\left(\mathrm{T}_{2}^{2}\right) ; 6$. Predominantly non-porous complex $\left(\mathrm{T}_{1}, \mathrm{P}^{2,3} \mathrm{~T}\right) ; 6 . \rightarrow$ Infiltration waters flow direction; 7. $\Rightarrow$ Thermal-mineral waters flow direction

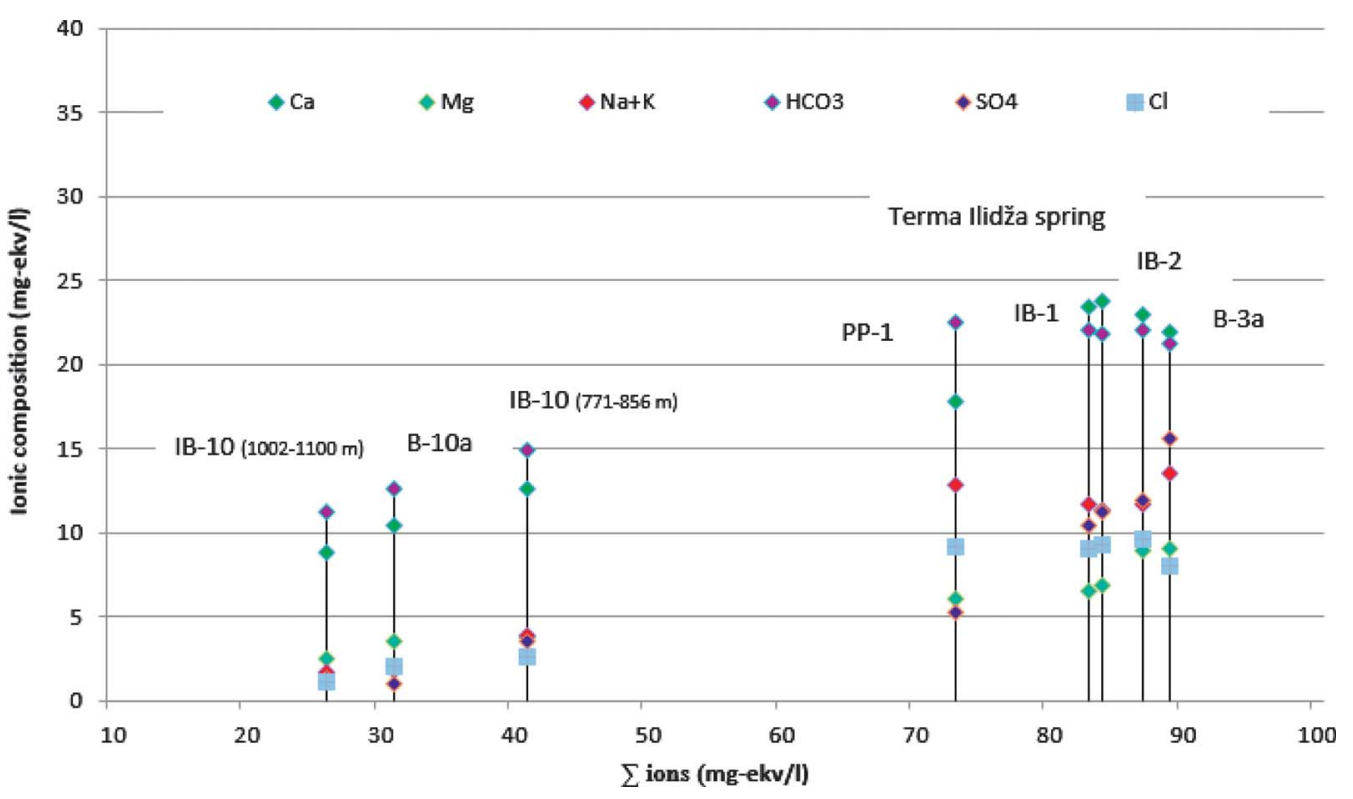

Figure 10: Water mixing diagram

Thermo-mineral water in the Ilidža area is a mixture of two waters, having different mineralizations (see Figure 10). Water mixing happens in the aquifer zone of Middle Triassic carbonates and waters from PermianTriassic deposits with evaporites at higher depths. The zone is not influenced by contemporary climatic factors which was proven by isotopic tests.

The temperature of TMWs of Ilidža varies in a wide range of 21 to $58^{\circ} \mathrm{C}$ due to the depths of infiltration of atmospheric waters and the geothermal gradients, static pressures in Permian-Triassic lens deposits due to dif- ferentiation in the Busovača Fault Zone, and dynamic factors while TMWs ascend through porous rocks at large distances under extremely high pressures. Large differences in the temperatures of TMWs found in drillholes that are relatively close together (for example, IB-2 $\left(59^{\circ} \mathrm{C}\right)$ and IB-10a $\left.\left(26^{\circ} \mathrm{C}\right)\right)$, temperature drops with increasing depths (for example, water at $775-920 \mathrm{~m}$ depth $\left(30^{\circ} \mathrm{C}\right)$, and at $\left.1100 \mathrm{~m}\left(20^{\circ} \mathrm{C}\right)\right)$, and the chemical and isotopic composition of water in the area of Ilidža. all indicate that Tertiary magmatism is not the heating source for rocks and the groundwater. 


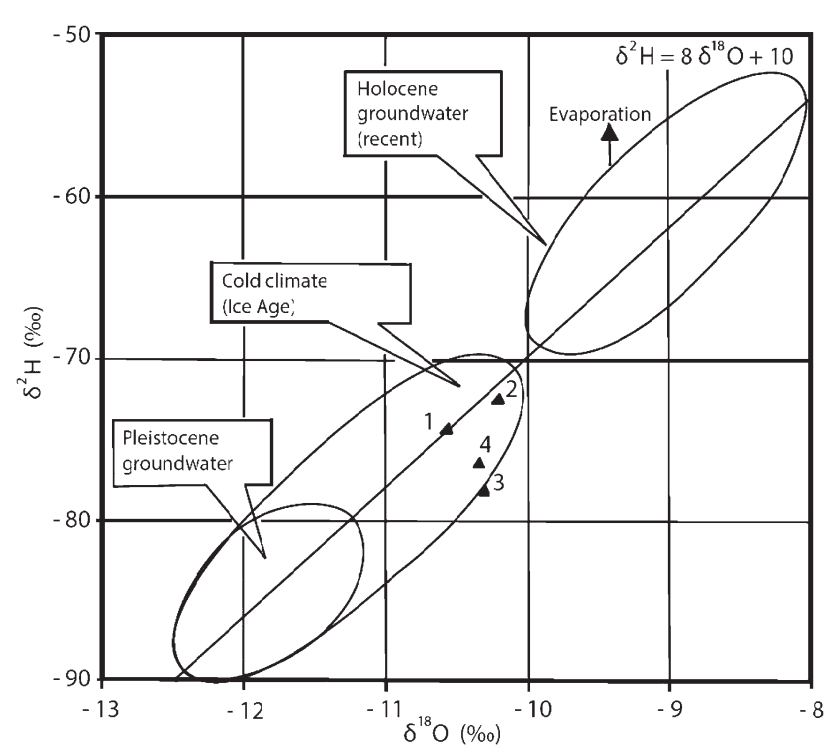

Figure 11.: The correlation between $\delta^{18} \mathrm{O}$ and $\delta^{2} \mathrm{H}$ of TMWs of Ilidža (Heidinger, 20oo; Skopljak, 2006). 1 - B-1 (2000); 2 - IB-1 (1985); 3 - IB-2 (1987); 4 - Izvor Terma (1984).

TMWs of Ilidža are of atmospheric origin, created in the Upper Pleistocene at a time of cold climate, most likely during Wirm's glaciation as indicated by deuterium $\delta^{2} \mathrm{H}$ and oxygen $\delta^{18} \mathrm{O}$ (see Figure 11).

The concentration of tritium $\left({ }^{3} \mathrm{H}\right)$ activity in the TMWs of Ilidža (about 1.7 TU) is an indicator of the dynamics of the recovery of some aquifers, that is, an indicator that TMWs have had no connection with the atmospheric or surface waters after 1952, or in other words, indicating a long-term retention in the ground (IAEA, 1983; Gonfiantini et al., 1998). The long retention period of TMWs is confirmed by the age of TMWs, as determined by the radioactive decomposition of ${ }^{14} \mathrm{C}$ in TMWs. The age of the water varies from 13,593 years (IB-2) to 32,937 years (B-3a). Such large variations in the age of TMWs, together with very similar physical and chemical characteristics requires further investigation, using the carbon isotope 14. From the aspect of groundwater recovery, it is a very unfavourable fact (Vlahović et al., 2009). During the conditions of deep infiltration of atmospheric water and long retention time in the underground, recovery of the reservoir of TMWs is difficult and is likely to take place over an extended period of time. This means that any excessive exploitation (especially by borehole drainage) above the optimum capacities can be detrimental to the reservoir by exploiting the static reserves of the TMWs. This can be accompanied by a continuous drop in pressure and water level in the reservoir, which can also cause changes in chemistry, temperature, or mixing with the marginal waters of different compositions. Sulphates in the TMWs of Ilidža originate mainly from the dissolution of evaporite deposits (gypsum and anhydrite), which suggests that these deposits also contribute to the structure at the bottom of the Sarajevo Basin. This is supported by the presence of Permian-Triassic and older (carbonate) deposits in the wider Ilidža area and the data obtained by testing the stable isotope content of sulfur-34 and oxygen-18 in the TMWs of Ilidža. The content of sulphate isotope in the B-1 well in Blažuj is $+23.2 \%{ }^{34} \mathrm{~S}$, and $+10.8 \%{ }^{18} \mathrm{O}_{- \text {so }}$ enters the area of the evaporative sulphate, indicating that sulphate originates from sulphate minerals, most likely gypsum and anhydrite. The slight presence of "light" secondary sulphates can be derived from the oxidation of reduced sulphur compounds, especially sulphides (pyrite) or organic aquatic components (Heidinger, 2000). Accordingly, the slight presence of secondary sulphate can be derived from oxidation of sulphide or pyrite, which is determined at several intervals in dolomite at the IB-2 well. The content of $\delta^{13} \mathrm{C}$ in TMWs of Ilidža $\left(0.96 \%\right.$ to $\left.+2.44 \% \delta^{13} \mathrm{C}\right)$ points to processes that have changed isotopically or increased the $\delta^{13} \mathrm{C}$ content from the initial formation of groundwater. These changes may have been caused by the mixing volcanic $\mathrm{CO}_{2}$ and/or carbonate solutions and by modifying the isotope with hydrogen carbonate rock. $\mathrm{CO}_{2}$ gas in the Ilidža area comes from the deeper horizons as indicated by geological, tectonic, and chemical elements. It is assumed that $\mathrm{CO}_{2}$ is of thermal-metamorphic origin, and it is created by the action of $\mathrm{SiO}_{2}$ on carbonates in deeper parts of the earth, where quartz-porphyrs have cut through the Paleozoic constituents. The deep Busovača Fault enables the gas to escape to the surface. The thermal-metamorphic origin of $\mathrm{CO}_{2}$ is also confirmed by the obtained $\delta^{13} \mathrm{C}-\mathrm{CO}_{2}$ carbon isotopes with values ranging from $0.18 \%$ to $2.36 \%$. This is also supported by $\delta^{13} \mathrm{C}$ $\mathrm{CO}_{2}$ of $-3.7 \%$ measured in the TMWs of Blažuj, as well as the results of TMW research around the world. Craig (1963), and Muffler and White (1968), based on their research carried out in the USA, New Zealand, and Italy, concluded that $\delta^{13} \mathrm{C}-\mathrm{CO}_{2}$ values from $-4 \%$ to $+4 \%$ point to the $\mathrm{CO}_{2}$ thermal-metamorphosis of marine carbonates, while Ceron (2000) believes that the content $\delta^{13} \mathrm{C} \%$ o $>-2$ indicates that $\mathrm{CO}_{2}$ is generated by the metamorphosis of carbonate rocks. The ${ }^{222} \mathrm{Rn}$ content in the TMWs of Ilidža was 1.40 to $2.30 \pm 0.4 \mathrm{~Bq} / \mathrm{kg}$. Such low $\mathrm{Rn}$ values indicate that the TMW does not move through rocks with a high content of uranium.

\section{Conclusions}

- The area in and around Ilidža is rich with carbonated karst aquifers where infiltrated water is retained and enriched during mineralization.

- The primary aquifer of TMWs are large PermianTriassic lenses of gypsum anhydrite, Lower Triassic sandstones of Sarajevo Basin, followed by carbonates of the Middle Triassic and Middle-to-Upper Triassic age.

- TMWs appear in the area where the Busovača Fault ends and it is broken in the multiple transverse and diagonal faults. 
- TMWs are of atmospheric origin and have had no contact with atmospheric or surface waters since 1953.

- The age of TMWs varies from 13,593 to 32,937 years.

- TMWs were created in the Upper Pleistocene, at the time of cold climate.

- Sulphates in TMWs of Ilidža originate from the evaporite (gypsum-anhydrite) deposits of PermianTriassic age.

- TMWs of Ilidža belong to $\mathrm{HCO}_{3}-\mathrm{SO}_{4}-\mathrm{Cl}-\mathrm{Ca}-\mathrm{Na}$ and $\mathrm{HCO}_{3}$-Ca types of water.

- TMWs of Ilidža contain $\mathrm{CO}_{2}$ gas, resulted from the metamorphosis of carbonate rocks in the deeper parts of the Earth's crust.

\section{References}

Afsin, M., Allen, D.M., Kirste, D., Durukan, G., Gurel, A. and Oruc, O. (2014): Mixing processes in hydrothermal spring systems and implications for interpreting geochemical data: a case study in Cappadocia Region of Turkey. In Special Issue on the Hydrogeology of Shallow Thermal Systems, Hydrogeology Journal, 22, 1, 7-23.

Bać, J. (1957): Pojava pregrijanih para na užem izvorišnom području termalnih izvora u Ilidži kod Sarajeva (The appearance of overheated steams in a narrow thermal spring area in Ilidža near Sarajevo), Zbornik radova II kongresa geologa FNRJ, Sarajevo, 614-616.

Buljan, M. (1962): New geochemical method of distinguishing the varieties of natural waters. Croatica Chemica Acta, 34, 13-23.

Ceron, J.C. (2000): CO2-rich thermo-mineral groundwater in the Betic Cordilleras, southeastern Spain: Genesis and tectonic implications, Hydrogeology Journal, 8, 2, 209-217.

Craig, H. (1963): Craig, H. (1961) Isotopic variations in meteoric waters. Science. 133, 1702-1703.

Gavrilenko, E.S. (1965): Hidrohemijski pokazatelji naftonosnosti po sonom i izotopskom sastavu podzemnih voda (Hydrochemical indicators of petroliferous capacity per sonic and isotopic composition of groundwater), Akademija Ukrajinske SSR, Kijev.

Goldscheider, N., Mádl-Szőnyi, J., Erőss, A.; Schill, E. (2010): Thermal water resources in carbonate rock aquifers. Hydrogeology Journal, 18, 6, 1303-1318.

Gonfiantini, R., Frohlich, K., Araguas-Araguas, L., Rozanski, K. (1998): Isotopes in Groundwater Hydrology. In: Kendall, C. and McDonnell, J.J. (eds.): Isotope Tracers in Catchment Hydrology, - Elsevier Science B.V., 203-246.

Heidinger, M. (2000): Rezultati određivanja sadržaja izotopa i gasova mineralne vode iz bunara "Ilidžanski dijamant" (Results of the determination of the isotope and gas content of mineral water of the well "Ilidžanski dijamant"), Hydroisotop GmbH, Schweitenkirchen.

Hem, J.D. (1985): Study and Interpretation of the Chemical Characteristics of natural Water. Washington: U.S. Geological Survey Water - Supply Paper, 2254 p.
IAEA (1983): Guidebook on Nuclear Techniques in Hydrology. Technical report Series No.91, International Atomic Energy Agency, Vienna.

Josipović, J. (1971): Mineralne, termalne i termomineralne vode na teritoriji Bosne i Hercegovine (Mineral, thermal and thermomineral waters in the territory of Bosnia and Herzegovina), Geološki glasnik,15, 233-275. Katzer, F. (1919.): K poznavanju mineralnih vrela Bosne (To know the mineral springs of Bosnia), Glasnik zemalj. muzeja $\mathrm{BiH}, 191-264$, Zemaljska štamparija, Sarajevo.

Kittl, E. (1904): Geologie der Umgebung vod Sarajevo. Jahrbusche d.geolog. Reichsanstalt. 53, 515-748.

Lu, L., Pang, Z., Kong, Y., Guo, Q., Wang, Y., Gu, W., Zhou, L., Yu, D. (2018): Geochemical and isotopic evidence on the recharge and circulation of geothermal water in the Tangshan Geothermal System near Nanjing, China: implications for sustainable development. In Special Issue on the Hydrogeology of Shallow Thermal Systems, Hydrogeology Journal, 26, 5,1705-1719.

Ludwig, E. (1894): Sumporovita banja Ilidže kod Sarajeva u Bosni (The sulphur spring of Ilidža near Sarajevo, Bosnia), 1 - 36., štamparija R. Waldheim, Wien.

Maréchal, J.C., Lachassagne, P., Ladouche, B., Dewandel, B., Lanini, S., Le Strat, P., Petelet-Giraud, E. (2014): Structure and hydrogeochemical functioning of a sparkling natural mineral water system determined using a multidisciplinary approach: a case study from southern France. Hydrogeology Journal, 22, 1, 47-68.

Miošić, N. (1982): Genetska kategorizacija mineralnih, termalnih i termomineralnih voda Bosne i Hercegovine ( $G e-$ netic categorization of mineral, thermal and thermomineral waters of Bosnia and Herzegovina), Geološki glasnik, 27, 241.

Mojsisovics, E., Tietze, E., Bittner, A. (1880): Grundlinien der Geologie von Bosnien und Hercegovina, Jahrbuch der Geologischen Reichanstalt. Wien.

Muffler, P. and White, D. (1968): Origin of $\mathrm{CO}_{2}$ in Salton Sea geothermal systems, southeastern California, USA. 23rd Int.Geol. Congr., Prague, 17.

Papić, P. (Ed) (2016): Mineral and thermal waters of Southeastern Europe. Environmental Earth Sciences, Springer International Publishing Switzerland, $171 \mathrm{p}$.

Petrini, R., Italiano, F., Ponton, M. Slejko, F. F.,Aviani, U.,Zini, L. (2013): Geochemistry and isotope geochemistry of the Monfalcone thermal waters (northern Italy): inference on the deep geothermal reservoir. Hydrogeology Journal, 21, 6, 1275-1287.

Skopljak, F. and Čičić, S. (2006.): Prilog poznavanju geneze termomineralne vode Ilidže kod Sarajeva (Contribution to the genesis of thermomineral water of Ilidža near Sarajevo), Geološki glasnik, 36, 112-136.

Skopljak, F. (2006): Odnosi podzemnih voda područja Ilidže kod Sarajeva (Relations of groundwater in Ilidža area near Sarajevo). Doktorska disertacija, Pos.izdanje Geol. glasnika, XXIX., Federalni zavod za geologiju, Sarajevo.

Skopljak, F. and Vlahović, T. (2011): The origin of mineral waters in Kiseljak near Sarajevo, Bosnia and Herzegovina, Environmental Earth Sciences, 66, 809-822.

Skopljak, F., Šarić, Ć., Pobrić, V. (2017): Contribution to the Genesis of Thermal Water of the North-east Perimeter of 
the Zenica-Sarajevo Basin, Bosnia and Herzegovina. The Mining-Geology-Petroleum Engineering Bulletin, 32, 4, 17-30.

Sulin, V.A. (1948): Basis of Classification of Natural Waters. Moscow, USSR.

Vlahović, T., Bačani, A., Posavec, K. (2009): Hydrogeochemical stratification of the unconfined Samobor aquifer (Zagreb, Croatia). Environmental Geology, 57, 8, 1707-1722.
Reports (with permission):

Pezdič, J. (1985): Izotopske analize vode, slobodnih plinova i radona bušotine IB-1 Ilidža. Institut Jožef Stefan, Ljubljana, Slovenia.

Pezdič, J. (1987): Izotopske analize vode, slobodnih plinova i radona bušotine IB-2 Ilidža. Institut Jožef Stefan, Ljubljana, Slovenia.

\section{SAŽETAK}

\section{Geneza termalno-mineralnih voda u okolici Ilidže, Bosna i Hercegovina}

Izvori termomineralnih voda Ilidže kod Sarajeva pojavljuju se na prijelazu vanjskih i unutarnjih Dinarida u Bosni i Hercegovini, tj. u čelu navlake bosanskoga fliša i krajnjemu jugoistočnom dijelu sarajevsko-zeničkoga kenozojskog bazena. Geneza termomineralnih voda Ilidže povezana je s geološkim strukturama, strukturno-tektonskim i hidrogeološkim značajkama terena padina Igmana i jugozapadnoga dijela sarajevskoga bazena. Šire područje Ilidže izgrađeno je od naslaga paleozojske, mezozojske i kenozojske starosti, a najvažnije tektonske strukture nastale boranjem, rasjedanjem i horizontalnim kretanjem jesu sinklinala Igman, busovačka rasjedna zona, uzdužni i poprečni rasjedi, Durmitorska navlaka i navlaka Blažuj - Lokve - Krupa. Složenost geotektonskoga sklopa širega područja Ilidže uvjetuje određene hidrogeološke značajke, te su na osnovi propusnosti izdvojene propusne i nepropusne stijene. Propusne stijene podijeljene su na: (1) propusne stijene međuzrnske; (2) propusne stijene pukotinske i (3) propusne stijene kavernozno-pukotinske propusnosti. Termomineralne vode Ilidže prvotno su nakupljene u permsko-trijaskim naslagama odakle uzlazno dotječu u trijaske karbonate i aluvijalne naslage, koje predstavljaju drugi vodonosnik gdje su termomineralne vode zahvaćene u brojnim bušotinama. Za određivanje geneze termomineralnih voda na području Ilidže uporabljeni su uzorci termomineralne vode s mjesta prirodnoga pražnjenja vodonosnika: izvor terma Ilidža te bušotina (PP-1, B-3a, IB-1, IB-2, IB-1o i B-10a) putem kojih se danas drenira vodonosnik. Prema sadašnjemu stupnju istraženosti i poznavanja geološke građe, strukturno-tektonskih i hidrogeoloških značajki terena, hidrogeokemijskih pokazatelja te podataka izotopskih ispitivanja utvrđeno je kako je temperatura termomineralnih voda Ilidže posljedica dubine infiltracije atmosferskih voda i geotermalnoga gradijenta, statičkih pritisaka u lećama permsko-trijaskih naslaga uslijed diferencijacije u zoni Busovačkoga rasjeda i dinamičkih faktora u fazi kretanja i ascendencije termomineralnih voda kroz šupljikave stijene na velikim udaljenostima te pod vrlo visokim tlakom. Termomineralne vode atmosferskoga su podrijetla te nisu bile povezane s atmosferskim ili površinskim vodama nakon 1953. godine. Starost termomineralnih voda varira od 13593 do 32937 godina. Nakupljene su tijekom gornjega pleistocena, u vrijeme glacijala. Sulfati u termomineralnim vodama potječu od evaporitnih (gipsno-anhidritnih) naslaga perma i trijasa, a u reduktivnim uvjetima iz sulfata je nastao $\mathrm{H}_{2} \mathrm{~S}$. $\mathrm{CO}_{2}$ ima podrijetlo u metamorfozi karbonatnih stijena u dubljim dijelovima Zemljine kore.

\section{Ključne riječi:}

vodonosnik, termomineralne vode, geneza, sulfati, Ilidža

\section{Authors contribution}

Dr. Ferid Skopljak, Assoc. Prof. led the research and conducted the field work. Dr. Tatjana Vlahović, Full. Prof. selected results for publishing and conducted the hydrochemistry analysis. Both authors equally contributed in article writing and preparation for publishing. 